\title{
Towards a biologically available strontium isotope baseline for Ireland
}

\author{
Christophe Snoeck ${ }^{\mathrm{a}, \mathrm{b}, \mathrm{c}, \mathrm{d}, *}$, Saskia Ryan ${ }^{\mathrm{e}, \mathrm{f}}$, John Pouncett ${ }^{\mathrm{b}}$, Maura Pellegrini ${ }^{\mathrm{b}, \mathrm{g}}$, Philippe Claeys ${ }^{\text {a }}$, \\ Ashlea N. Wainwright ${ }^{\text {c,h,i, }}$, Nadine Mattielli ${ }^{\mathrm{c}}$, Julia A. Lee-Thorp ${ }^{\mathrm{b}}$, Rick J. Schulting ${ }^{\mathrm{b}}$ \\ ${ }^{a}$ Research Unit: Analytical, Environmental \& Geo-Chemistry, Dept. of Chemistry, Vrije Universiteit Brussel, AMGC-WE-VUB, Pleinlaan 2, 1050 Brussels, Belgium \\ b School of Archaeology, University of Oxford, 1 South Parks Rd, Oxford, OX1 3TG, UK \\ c G-Time Laboratory, Université Libre de Bruxelles, ULB, CP 160/02, 50, Avenue F.D. Roosevelt, B-1050 Brussels, Belgium \\ ${ }^{\mathrm{d}}$ Maritime Cultures Research Institute, Dept. of Art Sciences E' Archaeology, Vrije Universiteit Brussel, MARI-LW-VUB, Pleinlaan 2, 1050 Brussels, Belgium \\ e Department of Geology, School of Natural Sciences, Trinity College, Dublin 2, Ireland \\ ${ }^{\mathrm{f}}$ UMR 7209, Archéozoologie, Archéobotanique: Sociétés, Pratiques et Environnements, CNRS, MNHN, Sorbonne Universités, CP 56,55 Rue Buffon, F-75005 Paris, France \\ g Thermo Fisher Scientific Italy, Str. Rivoltana, Km 4, 20090 Rodano MI, Italy \\ h School of Earth Atmosphere and Environment, Monash University, Clayton, VIC 3800, Australia \\ ${ }^{i}$ School of Earth Science, The University of Melbourne, VIC 3010, Australia
}

\section{H I G H L I G H T S}

- The strontium isotope baseline for Ireland shows ${ }^{87} \mathrm{Sr} /{ }^{86} \mathrm{Sr}$ from 0.7067 to 0.7164 .

- The baseline is based on $228{ }^{87} \mathrm{Sr} /{ }^{86} \mathrm{Sr}$ measurements from 140 locations.

- The median ${ }^{87} \mathrm{Sr} /{ }^{86} \mathrm{Sr}$ map must always be used with the median absolute deviation map.

- At a single location different plants can have very different values (up to 0.0052).

- Sampling multiple plants at each location is needed.

\section{A R T I C L E I N F O}

\section{Article history:}

Received 15 August 2019

Received in revised form 15 December 2019

Accepted 19 December 2019

Available online 20 December 2019

Editor: Mae Mae Sexauer Gustin

\section{G R A P H I C A L A B S T R A C T}
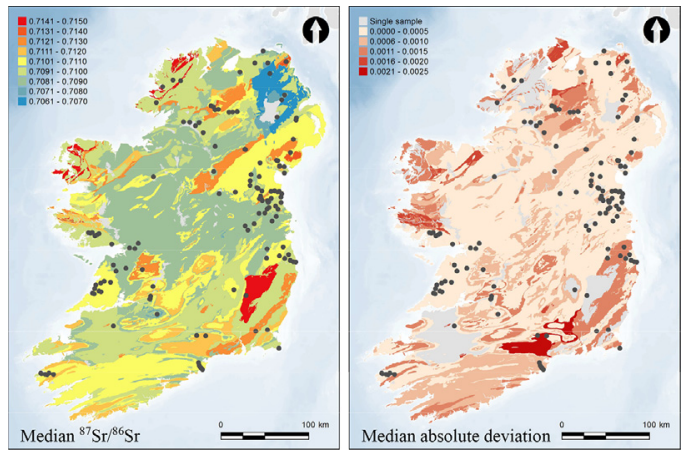

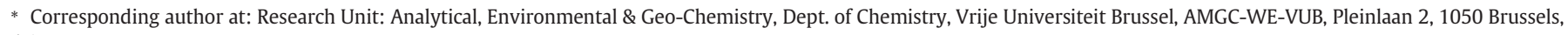
Belgium

E-mail address: christophe.snoeck@vub.be (C. Snoeck).
} 
Mountains. This variability confirms the potential for studying mobility and landscape use of past human and animal populations in Ireland. Furthermore, in some cases, large differences were observed between different types of plants from the same location, highlighting the need to measure more than one plant sample per location for the creation of BASr baselines.

Crown Copyright @ 2019 Published by Elsevier B.V. All rights reserved.

\section{Introduction}

Two isotopes of strontium, ${ }^{86} \mathrm{Sr}$ and ${ }^{87} \mathrm{Sr}$, are widely used in mobility studies. Their ratio $\left({ }^{87} \mathrm{Sr} /{ }^{86} \mathrm{Sr}\right)$ varies between different types of bedrock due to varying amounts of rubidium $(\mathrm{Rb})$ and to the passage of geological time, since the radioactive decay of ${ }^{87} \mathrm{Rb}$ produces ${ }^{87} \mathrm{Sr}$. A wide range of ${ }^{87} \mathrm{Sr} /{ }^{86} \mathrm{Sr}$ ratios are observed in the geosphere, with values ranging from about 0.7 to $>4.0$ due to different ages, original $\mathrm{Rb}$ to $\mathrm{Sr}$ ratios and initial ${ }^{87} \mathrm{Sr} /{ }^{86} \mathrm{Sr}$ (Faure and Powell, 1972). In Ireland, the highest values (0.9) are recorded for the granites of the Mourne Mountains (Meighan et al., 1988). After being incorporated into body tissues through consumption of plants, animals and liquids, ${ }^{87} \mathrm{Sr} /{ }^{86} \mathrm{Sr}$ can be measured in archaeological bone and teeth which in turn reflects the origin of the consumer's food at the time the tissue in question formed.

Several recent studies using strontium isotope analysis have focussed on human mobility in Ireland, extending from Neolithic to modern times (Beaumont et al., 2013; Cahill Wilson, 2012; Cahill Wilson and Standish, 2016; Kador et al., 2014, 2018; Knudson et al., 2012; Montgomery and Grimes, 2010; Ryan et al., 2018a; Sheridan et al., 2013; Snoeck et al., 2016; Wallace et al., 2010). Interpretation, however, has been hampered by the absence of a baseline map of bioavailable strontium for Ireland, such as that produced by Evans et al. (2010) for Britain.

To understand the strontium isotope variation observed in human or faunal remains of any period, it is necessary to construct a model or isoscape of biologically available strontium (BASr) not only around the sites of interest, but across the wider landscape (Bentley, 2006; Evans et al., 2009, 2010). Isoscapes describing spatial variation in the expected values of tracer isotopes have been generated either as continuous fields using geostatistical approaches (Bowen and Wilkinson, 2002; Ehleringer et al., 2008; Ostapkowicz et al., 2017), multi-source mixing models (Bataille and Bowen, 2012; Bataille et al., 2012) and machine learning (Bataille et al., 2018), or as discrete entities using variants of spatial aggregation (Kootker et al., 2016; Evans et al., 2018; Barberena et al., 2019). The former may be based directly on proxy data (e.g. modern plants or archaeological faunal remains) or may model the relative contributions of multiple factors that influence the spatial variation in the expected isotope values, while the later are typically based on proxy data aggregated by areal units (e.g. bedrock geology or soil parent material).

Archaeological faunal remains may be used to define a local ${ }^{87} \mathrm{Sr} /{ }^{86} \mathrm{Sr}$ range (e.g. Kootker et al., 2016), although they may have moved throughout their lifetime. Pigs are frequently preferred since they are considered to be less mobile than other fauna (Bentley et al., 2004; though see Madgwick et al., 2012). Rodent teeth may also serve the purpose but are not always available and their accumulation agents (e.g. owls) may have quite large home ranges (Copeland et al., 2010). Furthermore, archaeological faunal remains of whatever type are restricted to excavated sites, and so do not provide an unbiased coverage of biologically available strontium from the various geological formations present within the wider landscape (some of which may be inimical to bone preservation). Additionally, they do not allow a refined view of the small-scale variations in biologically available strontium to assess landscape use, as they will most likely average plants growing on different substrates. Still, in densely populated regions and heavily managed areas, such as the Netherlands, where non-anthropogenically altered areas are extremely limited, modern environmental samples might not represent (pre)historic conditions. In that case, archaeological remains of small animals (e.g. rodents) represent an ideal proxy (Kootker et al., 2016). This is, however, not the case in Ireland, where enough minimally anthropogenically altered areas are still present.

Water samples are also problematic, as environmental water usually contains very little strontium and sources can be mixed and use of agricultural lime and other types of fertilisers introduces modern contamination (Thomsen and Andreasen, 2019). Plant samples have been shown to better represent the BASr than soil leachates and streamwaters, since they represent the strontium that is directly incorporated into the biosphere (Ryan et al., 2018b).

Strontium isotope composition of the biosphere in Ireland is strongly influenced by the local bedrock geology (Ryan et al., 2018b; Snoeck et al., 2016). Geological maps can therefore be used as templates, at least initially, to create broad BASr zones. However, observed differences between the strontium isotope compositions of the biosphere and the underlying bedrock can result from certain factors such as surficial deposits, seaspray, atmospheric deposition and rainwater, and thus, directly evaluating BASr values across the study area is crucial (Montgomery, 2010; Ryan, 2017; Ryan et al., 2018b; Sillen et al., 1998).

The bedrock of Ireland is mainly composed of Palaeozoic rocks (542-251 Ma) with a few Mesozoic outcrops (251-65 Ma) and a large Tertiary volcanic basalt lava outcrop (c. $60 \mathrm{Ma}$ ) in the northeast of the island (Co. Antrim) (Holland and Sanders, 2009). A detailed geological map combining the results of the Geological Survey of Ireland (GSI) and the Geological Survey of Northern Ireland (GSNI) (GSNI - Geological Survey of Northern Ireland, n.d) records the presence of 83 different geological formations across the island (Fig. 1). Overlying the bedrock in some areas are surficial deposits composed, among other things, of peat bogs and glacial till originating mostly from the last deglaciation around 14,000 BP. Prior to this, most of Ireland was covered by an ice sheet (GSI - Geological Survey of Ireland, n.d.; Clark et al., 2012). Peat is mostly present in the western and central parts of the island (Hammond, 1981; Connolly et al., 2007). More locally the impacts of alluviation and colluviation can blur geological boundaries.

A number of recent studies have presented strontium isotope measurements carried out directly on plant samples, focussing on Northern Ireland (Snoeck et al., 2016), Co. Meath (Cahill Wilson and Standish, 2016; Ryan et al., 2018b) and on coastal areas around the island to investigate seaspray effects (Snoeck, 2014; Ryan, 2017). The results demonstrated spatial variation in biologically available strontium, supporting their use as an effective tool for provenance studies in Ireland, but they were incomplete in coverage. Therefore, to construct a map of biologically available strontium for Ireland, we collected and analysed a series of georeferenced modern plants, following the strategy of similar studies elsewhere (Evans et al., 2009, 2010; Copeland et al., 2010, 2011; Hartman and Richards, 2014; Laffoon et al., 2012; Schulting et al., 2018). Here, we combine previously published and new measurements on plants within a GIS-based spatial model to create the first baseline of the biologically available strontium isotope ratios for the island of Ireland.

\section{Materials \& methods}

\subsection{Plant sampling strategy}

Several considerations must be kept in mind when sampling modern plants to establish the BASr of a study area. Anthropogenically modified fields should be avoided since fertilisers and pesticides could 
00 - Coastal Zone

01 - Metadolerite or

02 - Serpentinite, DX

03 - Orthogneiss Suite, Connemara

04 - Ordovician Granite

05 - L Palaeozoic Dolerite, Diorite

06 - Palaeozoic Felsic Minor Intrusion

07 - Caledonian Appinite Suite

08 - Caledonian Granite

09 - Tertiary Granite, Felsite

10 - Tertiary Rhyolite (Volcanics and Intrusions)

11 - Tertiary Basic Intrusion

12 - Rhinns Complex

13 - Mullet Gneiss

14 - Cross Point Gneiss

15 - Doolough Granite and Gneiss

16 - Kilmore Quay Group

17 - Greenore Point Group

18 - Tyrone Central Inlier

19 - Slishwood Division

21 - Dalradian Grampian Group

22 - Dalradian Appin Group Quartzite

23 - Dalradian Appin Group

24 - Dalradian Argyll Group Paragneiss

25 - Dalradian Argyll Group Volcanics

27 - Dalradian Argyll Group

28 - Dalradian S Highland Group Volcanics

29 - Sperrins Dalradian (Position Uncertain)

30 - Cambrian Quartzite

31 - Cambrian Slate

32 - Cambrian Greywacke, Sandstone, Quartzite

33 - Lr-Mid Ordovician Basic Volcanics

34 - Lr-Mid Ordovocian Acid Volcanics

35 - Lr-Mid Ordovician Slate

36 - Lr-Mid Ordovician Greywacke, Sandstone

37 - Mid-Up Ordovician Basic Volcanics
38 - Mid-Up Ordovician Acid Volcanics

39 - Mid-Up Ordovician Slate

40 - Derryveeny Formation

41 - Ordovician or Silurian Melange

42 - Rathkenny Formation

43 - Dunquin Group, Dingle

44 - Silurian Volcanics

45 - Croagh Patrick Suc
46 - Silurian Quartite

46 - Silurian Quartzite

47 - Louisburgh - Clare Island Succession

48 - Killary - Joyces Succession

49 - Silurian Sandstone, Greywacke, Shale

50 - Devonian Basic Volcanics, Minor Intrusions

51 - Devonian Acid Volcanics

52 - Up Silurian - Lr Devonian ORS

53 - Mid Devonian OR

54 - Up Devonian-Lr Carboniferous ORS 55 - Up Devonitane

56 - Carbonicor Intrusions

57 - Courceyan Mudstone, Sandstone

59 - Courceyan 'Bone Shale

60 - Navan Group

60 - Navan Group

61 - Courceyan Limestone

62 - Waulsortian Mudbank

64 - Marine Shelf Facies

65 - Visean Basinal Limestone 'Calp'

66 - Tyrone Group; Visean Mudstone, Sandstone

67 - Armagh Group

68 - Leitrim Group; Visean Mudstone, Sandstone

69 - Ballycastle Succession

70 - Late Visean-Westphalian 'ORS'

71 - Namurian Sandstone, Shale

72 - Westphalian Shale, Sandston

73 - Permian Sandstone

74 - Permo-Trias Sandstone

75 - Triassic Sandstone

76 - Lr Jurassic Mudstone

77 - Up Cretaceous Limestone

78 - Tertiary Minor Volcanics

79 - Lower Basalt Formation

80 - Interbasaltic Formation Laterite, Bauxite

81 - Causeway Tholeiite Member

82 - Upper Basalt Formation

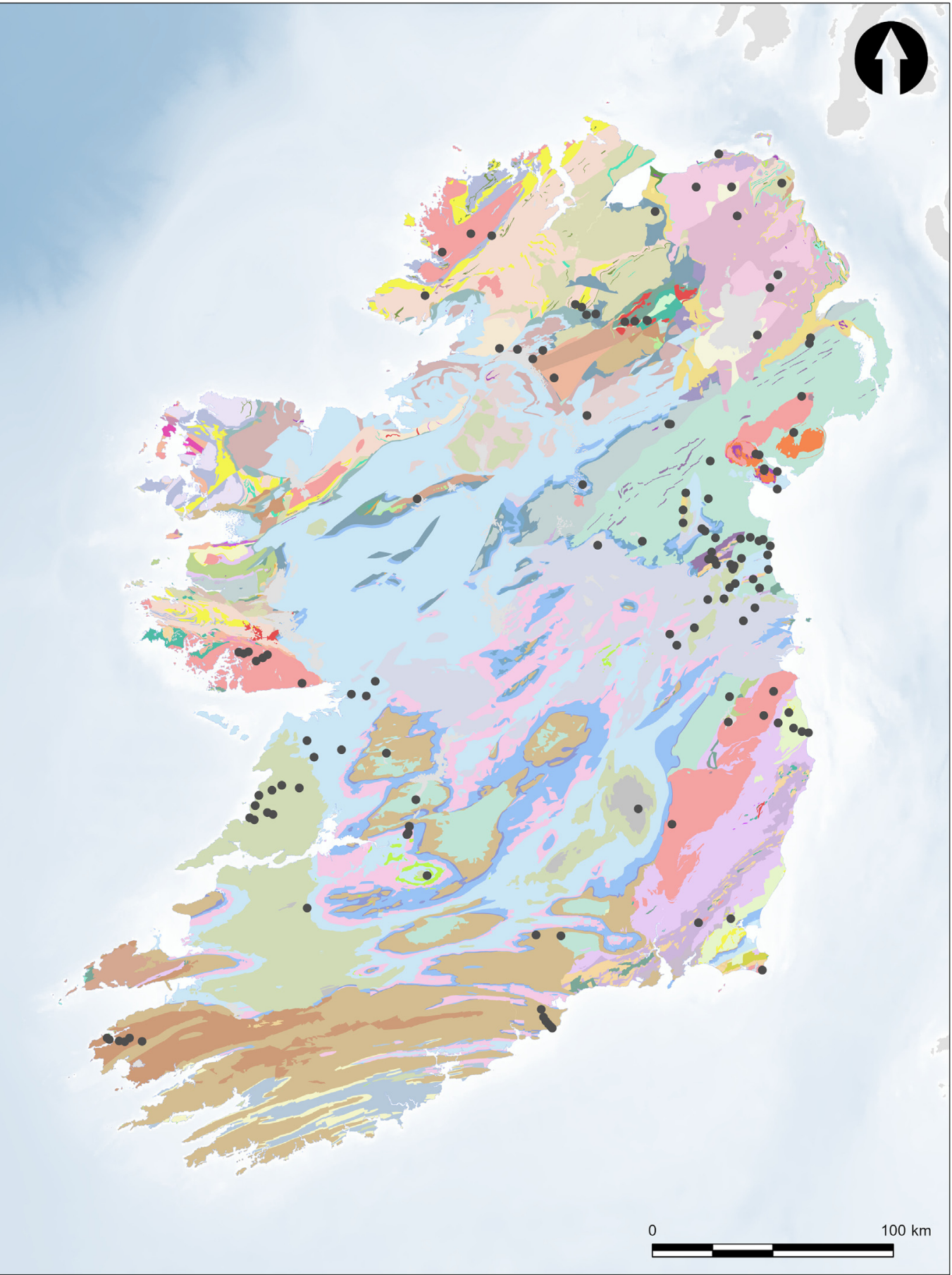

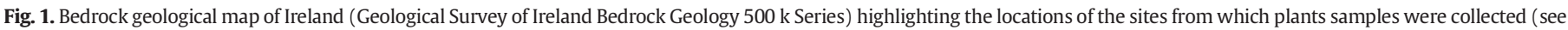
Table S2 for references).

introduce other sources of strontium (e.g. Thomsen and Andreasen, 2019). In river plains, sediments are likely to reflect a mixture of strontium from different source areas, while along the coasts, seaspray effects can impart the modern ocean ${ }^{87} \mathrm{Sr} /{ }^{86} \mathrm{Sr}$ value of 0.7092 (Hess et al., 1986) for variable distances inland (Whipkey et al., 2000; Snoeck, 2014; Ryan, 2017).

As plants obtain their strontium from the soil through their roots, only a limited area (or microhabitat) is sampled: trees, shrubs and grasses have different rooting lengths and depths which impacts on the size of the area from which they take up strontium (Poszwa et al., 2002; Reynolds et al., 2012). This may influence their strontium isotope composition depending, among other things, on surficial deposits (e.g. presence of peat bog), bedrock heterogeneity and local contamination (e.g. fertilisers; local soil movement). Additionally, in regions with high topographic relief, erosion should be taken into consideration.

These considerations were taken into account here and, where possible, samples were taken as far away as possible from heavily modified arable fields and developed land, i.e. focussing instead on parkland, forests, etc. To avoid sampling potentially anomalous 'microhabitats', several kinds of plant samples were taken at each site, including grass, shrub and tree and where possible, leaves/branches from three different shrubs/trees of the same species. Nevertheless, it is accepted that it is not possible to completely avoid recent anthropogenic impacts. To deal with this, outliers must be detected and removed from the dataset. 
If six or more samples were measured for a single outcrop (i.e., samples taken from the same contiguous geological formation), the outlier detection was based solely on that outcrop. If fewer than six measurements were available, outlier detection was based on all the samples measured on that geological formation across the island. Measurements removed by more than 3SD from the average of the outcrop/formation were considered to be outliers.

A total of 239 strontium isotope ratios were measured on plants samples collected from 140 distinct locations in Ireland (Table S2). Of these, 176 are from previously published studies (Snoeck et al., 2016: 92; Deegan, 2012: 8; Ryan et al., 2018b: 33; 2017: 38; Cahill Wilson and Standish, 2016: 5), to which 63 new measurements of plants from 30 different locations have been added. These samples were selected based on the underlying bedrock geology with a view to cover the main geological units in Ireland. GPS coordinates were recorded for each site (Table S2) as well as distance from major roads, rivers and the coast. At each site, several digital photos were also taken. To ensure full comparability of the results, all samples were normalised to the SRM987 value of 0.710248 (Weis et al., 2006) as some of the previously published datapoints were normalised using a value of 0.710250 for SRM987.

\subsection{Grouping the different geological formations}

Ideally, several plant samples should be taken from each geological outcrop to create a continuous map of the biologically available strontium. However, due to anthropogenic impacts on the modern landscape, this is not always possible, and we were often restricted to areas with very limited or no anthropogenic impact. Cost and sampling time could also be prohibitive depending on the resolution of coverage sought and size of the study area. Instead, different ways to evaluate the biologically available strontium isotope ratios of non-sampled areas must be found. Here, the 83 lithological formations present in Ireland are reclassified into seven groups (Tables 1 \& S1). As previously described, the strontium composition of a rock is controlled by its mineral content/chemical composition and age. Therefore, these geological groups were categorised based on their type, and clastic sediments were further distinguished based on their age as they represent the largest group.

\subsection{Strontium isotope analyses}

The plant samples were dried naturally, crushed with a stainlesssteel coffee grinder before being ashed in porcelain crucibles at $650{ }^{\circ} \mathrm{C}$ in a muffle furnace by step heating for up to $8 \mathrm{~h}$. To avoid any cross contamination between samples, the inside and blade of the grinder were rinsed thoroughly with MilliQ water and dried with a pressurised air cleaner. The crucibles were rinsed with MilliQ water and placed overnight in a $2 \mathrm{M}$ subboiled $\mathrm{HNO}_{3}$ bath before being rinsed again and dried at $50{ }^{\circ} \mathrm{C}$ in an oven. Strontium was extracted from the ashed samples and purified following the protocol described in Snoeck et al. (2015) and measured on a Nu Plasma MC-ICP-MS (Multi-Collector Inductively Coupled Plasma Mass Spectrometer; Nu015 from $\mathrm{Nu}$

Table 1

Classification of the 83 different lithological formations present in Ireland (see Table S1).

\begin{tabular}{ll}
\hline$\#$ & Geological groups based on type and/or age (class) \\
\hline 0 & Coastal zone \\
1 & Metamorphic \\
2 & Felsic/intermediate igneous \\
3 & Clastic sedimentary: Ordovician, Silurian, Devonian \\
4 & Clastic sedimentary: Carboniferous, Permian, Triassic, Jurassic, \\
& Cretaceous \\
5 & Chemical sedimentary \\
7 & Mafic igneous \\
\hline
\end{tabular}

Instruments, Wrexham, UK) at the Université Libre de Bruxelles (ULB). During the course of this study, repeated measurements of the NBS987 standard yielded ${ }^{87} \mathrm{Sr} /{ }^{86} \mathrm{Sr}=0.710214 \pm 0.000040$ (2SD for 15 analyses), which is, for our purposes, sufficiently consistent with the mean value of $0.710252 \pm 0.000013$ (2SD for 88 analyses) obtained by TIMS (Thermal Ionization Mass Spectrometry) instrumentation (Weis et al., 2006). The ${ }^{83} \mathrm{Kr}$ and ${ }^{85} \mathrm{Rb}$ beam intensities were continuously monitored to prevent any spectral interference; the intensities were always below $0.05 \mathrm{mV}$, which is negligible compared to the total Sr beam intensity (7-8 V). All the data were corrected for mass fractionation by internal normalisation to ${ }^{86} \mathrm{Sr} /{ }^{88} \mathrm{Sr}=0.1194$. All measurements were normalised externally using a standard bracketing method with the recommended value of ${ }^{87} \mathrm{Sr} /{ }^{86} \mathrm{Sr}=0.710248$ for NBS987 (Weis et al., 2006). Procedural blanks were considered negligible (0.02 total $\mathrm{Sr}(\mathrm{V})$ versus $7-8 \mathrm{~V}$ for analyses; i.e. $\approx 0.3 \%)$. For each sample the ${ }^{87} \mathrm{Sr} /{ }^{86} \mathrm{Sr}$ value is reported with a $2 \sigma$ error (absolute error value of the individual sample analysis - internal error).

\subsection{Creation of the BASr maps}

A BASr baseline for Ireland was generated using multi-level spatial aggregation - a method of spatial aggregation that replicates the functionality of the Summarize Within tool in ArcGIS Pro $2.4^{1}$ and extends it to calculate both parametric and non-parametric statistics and extrapolate summary statistics for input polygons (geological formations) that do not contain summary features (modern plant samples). The method aggregates samples by bedrock geology and calculates parametric and non-parametric statistics that describe the variation in the observed ${ }^{87} \mathrm{Sr} /{ }^{86} \mathrm{Sr}$ ratios. Samples are aggregated iteratively using polygons from the Geological Survey Ireland Bedrock Geology 500 k Series in the following order of priority (https://www.gsi.ie/en-ie/data-andmaps/Pages/Bedrock.aspx\#):

- Level 0 (Outcrop) - the GSI polygons are split into single part features and used to aggregate samples by outcrop;

- Level 1 (Formation) - the GSI polygons are retained as multi-part features and used to aggregate samples by formation;

- Level 2 (Group - Table 1) - the GSI polygons are reclassified by type/ age and used to aggregate samples by classification.

Descriptive statistics (count, minimum, maximum, range, mean, standard deviation, lower quartile, median, upper quartile, interquartile range and median absolute deviation) were calculated from the isotope ratios for the samples corresponding to each outcrop, formation or type/ age. Polygons for the different levels of spatial aggregation are updated in reverse order to compile a baseline comprised of contiguous polygons with expected ${ }^{87} \mathrm{Sr} /{ }^{86} \mathrm{Sr}$ ratios. The BASr baseline can be updated to include additional samples using the Jupyter notebook or Python script tool which are provided in the companion paper (Pouncett et al., n.d.).

This method is broadly comparable to the isotope package model initially developed for the Isle of Skye (Evans et al., 2009) and later applied to the rest of Britain (Evans et al., 2010); however, the Irish model differs from the isotope package model in two key ways: 1) input from seaspray is accounted for by defining a polygon for the coastal zone using a $50 \mathrm{~m}$ buffer (cf. Snoeck et al., 2016); and 2) input from rainfall and atmospheric dust is accounted for by splitting formations into smaller single-part polygons which implicitly reflect the effects of local variation in annual precipitation and other air-borne particles (e.g. dustfall).

\footnotetext{
1 The script tool is also compatible with ArcGIS Desktop 10.5 or later.
} 


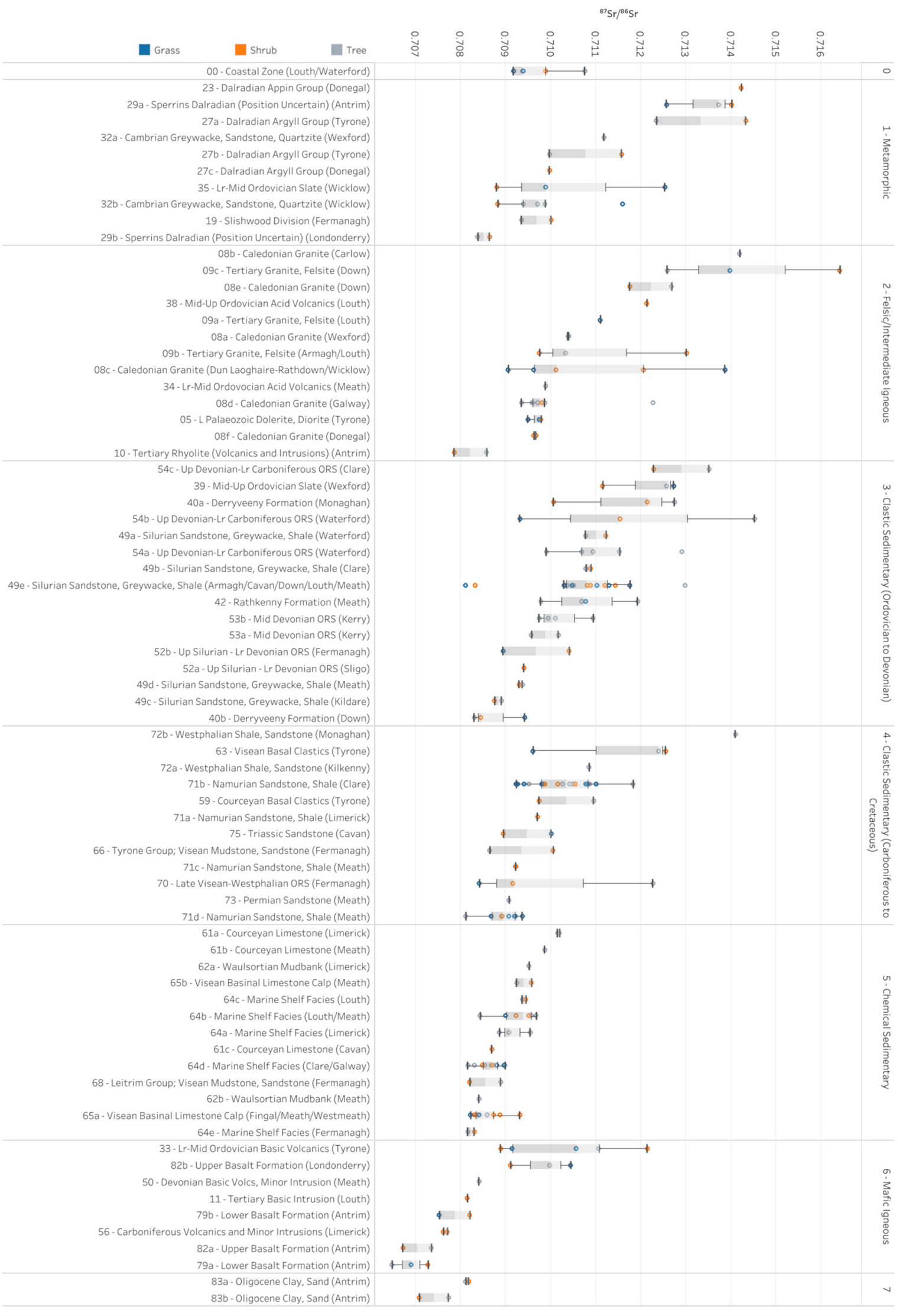

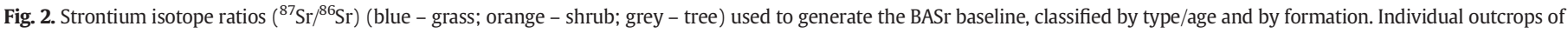

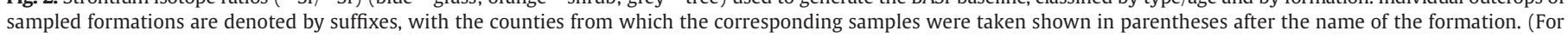
interpretation of the references to colour in this figure legend, the reader is referred to the web version of this article.) 


\section{Results}

The strontium isotope ratios of the sampled plants (Table S2) ranged from 0.7067 to 0.7663 , with the highest value being a definite outlier. A total of 11 samples (out of 239) were classified as outliers (as defined above), representing $<5 \%$ of the entire dataset. These comprised seven grasses, two shrubs and two trees. After their removal, the range of observed values is 0.7067 to $0.7164(n=228)$, which is broadly comparable to that seen in Britain (0.7061 to 0.7266; $n=126$; Evans et al., 2010).

Marked variation can be seen in the strontium isotope ratios of samples from different bedrock geologies (Fig. 2). As expected, the isotope ratios for samples from chemical sedimentary and clay/sand formations (Groups 5 and 7) are relatively homogeneous, while those from the metamorphic, felsic/intermediate igneous, clastic sedimentary and mafic igneous formations (Groups 1 to 4 and Group 6) are more heterogeneous as they tend to have isotopic fingerprints, specific to each formation. The continuous distributions of values for the clastic sedimentary formations (Groups 3 and 4), which more closely reflect the distributions of values for the chemical sedimentary and clay/sand formations can be contrasted with the discontinuous distributions of values for the metamorphic and mafic igneous formations (Groups 2 and 6), which appear to fall into three subgroups $\left({ }^{87} \mathrm{Sr} /{ }^{86} \mathrm{Sr}\right.$ ratios $<0.7090,0.7090-0.7120$ and $>0.7120$ ).

The difference between different types of sampled plants (trees, shrubs and/or grasses) was evaluated in 62 locations. The results show that some locations exhibit extremely low variations between plant types $\left(\Delta^{87} \mathrm{Sr} /{ }^{86} \mathrm{Sr}<0.0001\right)$, while others show much higher variation of up to 0.0052 (I79; Outcrop 54b on Fig. 2). Rainfall impact was also assessed. Annual rainfall $(\mathrm{mm})$ for Ireland was calculated from the $30 \mathrm{~s}$ WorldClim Version 2 long-term monthly average (1970 to 2000) precipitation data (Fick and Hijmans, 2017). There is a weak but significant positive correlation between the strontium isotope ratios and annual precipitation for the plant samples used to generate the BASr baseline (Spearman's rho test, $\rho=0.225, n=225^{2}, p<0.001$ ). The strontium isotope ratio of rainwater in coastal areas is equivalent to that of modern seawater, i.e. 0.7092 (Hess et al., 1986). While in most situations the input of rainwater is unlikely to have a significant direct impact on BASr because of its low strontium content, areas of higher annual rainfall, typically uplands with increased surface runoff which, depending upon the local bedrock geology, may have a significant indirect impact upon BASr (cf. Bataille and Bowen, 2012). The input of rainfall, whether directly through rainwater or indirectly through surface runoff, is taken into account in the model used to generate the BASr baseline by creating single part polygons for the bedrock geology and aggregating the modern plant samples by outcrop where possible. Trends in the strontium isotope ratios and annual rainfall for the Marine Shelf Facies (Formation 64) and Namurian Sandstone and Shale (Formation 71) are clearly captured in the outcrops from different counties (Fig. 3). Rather than converging on the ocean value of 0.7092 , higher rainfall seems to result in greater contributions from the bedrock geology. Thus, ${ }^{87} \mathrm{Sr} /{ }^{86} \mathrm{Sr}$ values for Carboniferous limestones (Formation 64 ) in counties with higher rainfall are more likely to yield the expected values of 0.7080-0.7085 (Veizer et al., 1999), while sandstones and shales (Formation 71) show a trend towards more radiogenic values, consistent with their formations from older metamorphic parent materials (cf. Evans et al., 2010). Some of the variation in plants growing on the two formations probably relates to 'bleeding' between them at their interfaces.

All 228 values were retained for coincident points for the purposes of generating the BASr baseline. In the second instance, polygons for Quaternary Geomorphology and Sediments were downloaded from the Geological Survey of Ireland (https://www.gsi.ie/en-ie/data-and-

\footnotetext{
23 samples have null values for annual rainfall and were excluded from the Spearman's rho test.
}

Formation 64 - Marine Shelf Facies

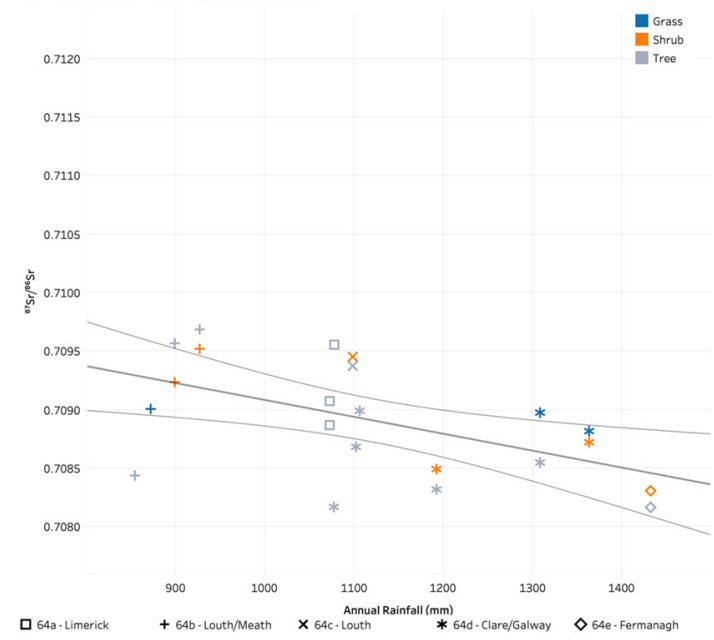

Formation 71 - Namurain Sandstone, Shale

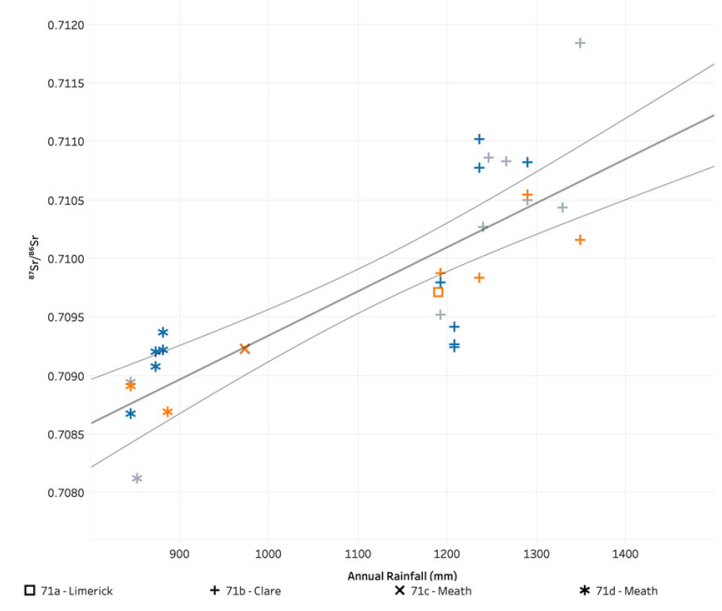

Fig. 3. Correlation between strontium isotope ratios $\left({ }^{87} \mathrm{Sr} /{ }^{86} \mathrm{Sr}\right)$ and annual rainfall for plant samples on outcrops of (left) Marine Shelf Facies (Formation $64-r^{2}=0.3000$ $p=0.0083$ ) and (right) Namurian Sandstone and Shale (Formation $71-r^{2}=0.6611$ $p<0.0001$ ) in different counties.

maps/Pages/Quaternary.aspx\#). Strontium isotope ratios for samples from formations with both outcrops/subcrops of bedrock documented by the GSI and one or more Quaternary sediments were compared (Fig. 4). With the exception of the gravels derived from Lower Palaeozoic sandstones and shales, which locally overlay the Silurian Sandstone, Greywacke and Shale in Co. Cavan (Formation 49e), there is no significant difference in the strontium isotope ratios for the bedrock and the overlying surficial deposits. At this stage, therefore, we have not modelled superficial deposits for the purposes of generating the BASr baseline for Ireland, although this would be worth revisiting in future work (Fig. 5).

The 228 strontium isotope ratios measured on plant samples from 140 unique location are overall not normally distributed (ShapiroWilk text, $\mathrm{W}=0.949, \mathrm{df}=228, p=0.000$ ) and so non-parametric statistics were consequently used to describe their spatial variation. The median BASr values (Fig. 5a) range from $0.706896 \pm 0.000372$ 2MAD $(n=3)$ for the Lower Basalt Formation in Co. Antrim (Formation 79a - Mafic Igneous) to $0.714236(n=1)$ for the Dalradian Appin Group in Co. Donegal (Formation 23 - Metamorphic). The median absolute deviation - the median of the absolute difference (MAD) between the value of each sample from an individual outcrop/formation and the median for the outcrop/formation - provides an estimate of the variation in the isotope ratios. MAD (Fig. 5b) varies between $0.000002(n=2)$ for the Tertiary Basic Intrusion in Co. Louth (Formation 11 - Mafic Igneous) 


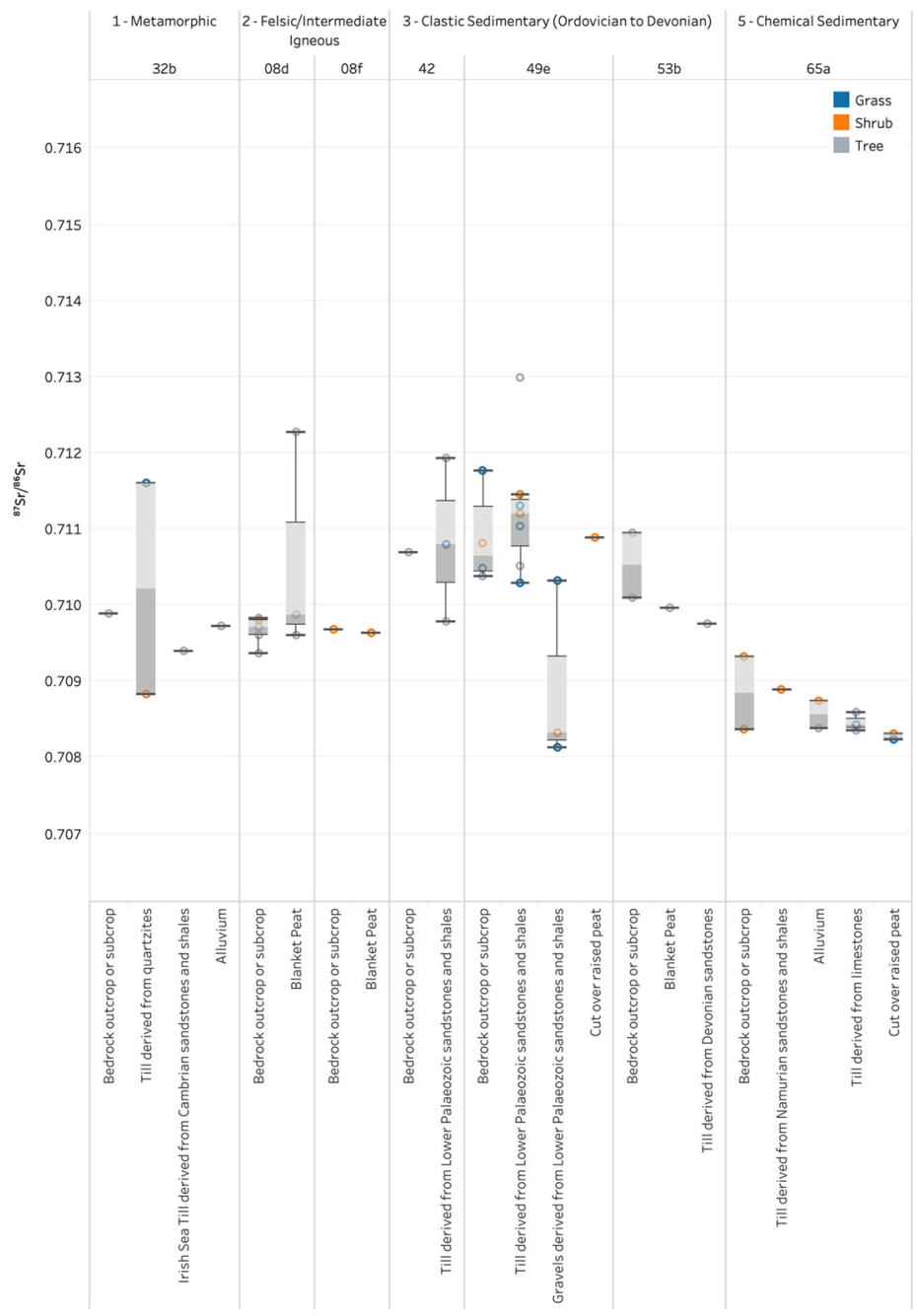

Fig. 4. Comparison of strontium isotope ratios $\left({ }^{87} \mathrm{Sr} /{ }^{86} \mathrm{Sr}\right)$ for bedrock outcrops/subcrops and superficial deposits from the same formations.

and $0.002217(n=3)$ for the Upper Devonian/Lower Carboniferous Old Red Sandstone in Co. Waterford (Formation 54b - Clastic Sedimentary (Ordovician to Devonian)). Variation in the isotope ratios may be determined by the type/age of an outcrop/formation or alternatively may simply reflect the number of samples or spatial extent of the outcrop/ formation.

Values for outcrops that were sampled directly (Level 0) take into account local variation in rainfall and consequently should be considered to be more reliable than those based on samples from a different outcrop but of the same formation type (Level 1) or based on the type/age groups (Level 2). Outcrops that were sampled directly (Fig. 5c) represent $59.66 \%$ of Ireland by surface area and in turn correspond to formations that together represent a total of $92.97 \%$ of Ireland by surface area. The number of samples taken per outcrop (Fig. 5d), ranged between 1 for the Caledonian Granite in Co. Carlow (Formation $8 \mathrm{~b}$ - Felsic/Intermediate Igneous) and 18 for the Namurian Sandstone and Shale in Co. Clare (Formation 71b - Clastic Sedimentary (Carboniferous to Cretaceous)). Higher numbers of samples were typically taken from outcrops/formations surrounding the Neolithic chambered tombs at Newgrange and Knowth on the River Boyne in Co. Meath and Parknabinnia in Co. Clare reflecting the origins of the dataset being initially used to characterise the areas around these sites. Obvious gaps can be seen in the distribution of samples and as such, the collection of additional plant samples from west, southwest and central Ireland should be seen as a priority.

\section{Discussion}

The results presented here clearly show the variability in isotope ratios of the biologically available strontium in Ireland. While the bedrock geology is an important contributor to the strontium isotope ratios of the plants, it is not the only one. Indeed, different values are observed for different outcrops of the same geological formation (Fig. 2), which probably reflects the impact of varying input of rainfall and dust, or, to a lesser extent, surficial sedimentary deposits - though, as Fig. 3 demonstrates, the relation with rainfall is complex. This highlights the need to sample plant material rather than rely on values obtained from the bedrock. The presence of peat bogs, however, seems to have a limited impact. At sampling site A03 (Table S2), peat bogs were clearly visible. Two samples (grass and shrub) were taken about $100 \mathrm{~m}$ from the bog and an additional one (grass) was taken on top of the bog itself. The values are similar for all three samples ( 0.7095 and 07098 close to the bog and 0.7098 from the bog, all elevated above the value of rainfall), which might be linked to the acidity of peat bogs. They might, hence, be in chemical equilibrium with the underlying soil and geological formation, though this is based on only three samples.

The impact of seaspray on the coastal plant transects in Ireland has been investigated in detail by Ryan (2017) showing a clear impact on the strontium isotope ratios of plants with values approaching that of seawater for plants growing near the coast $(<50 \mathrm{~m})$ and more disparate values for those further away. Indeed, samples from sites I17 and I21 

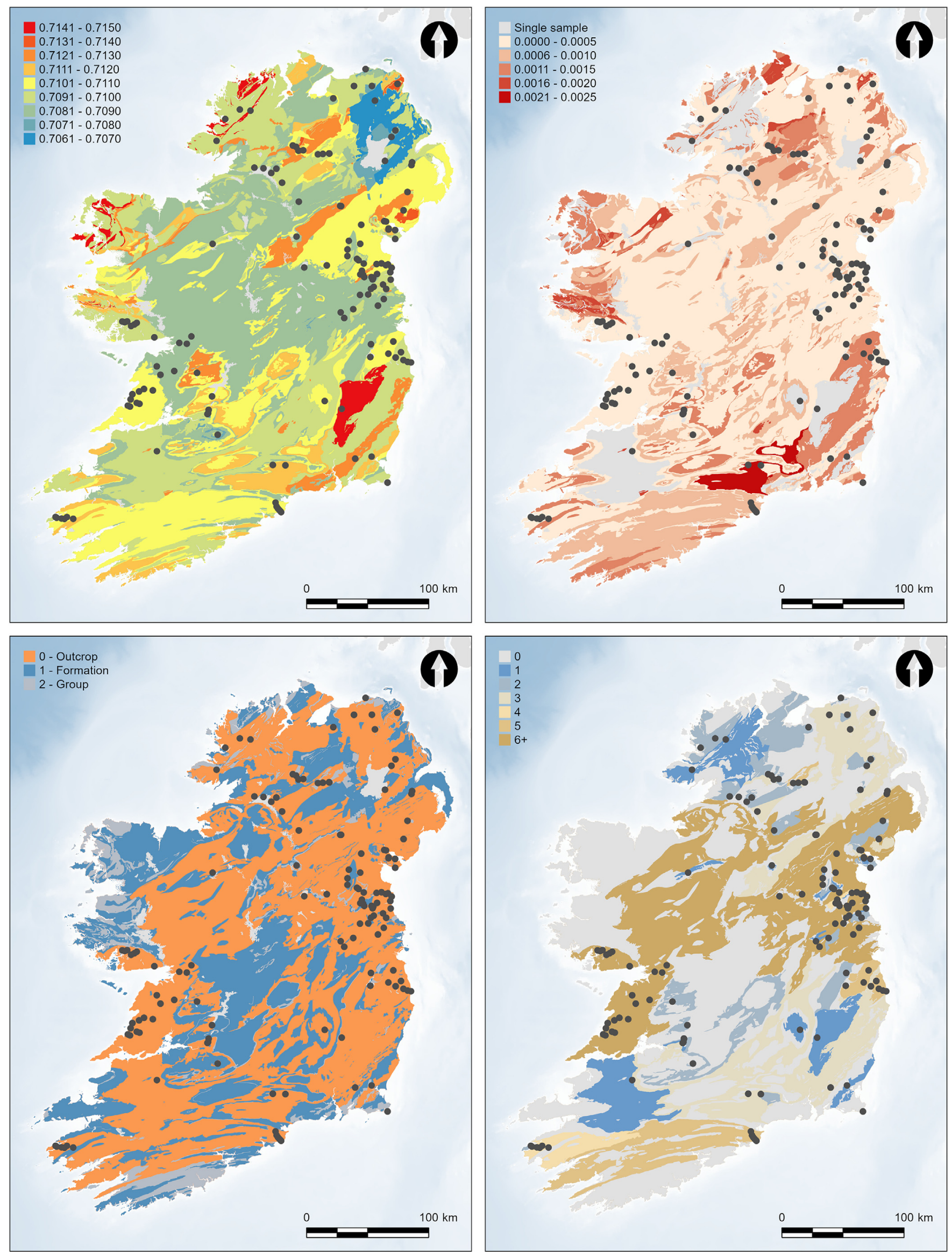

Fig. 5. BASr baseline for Ireland: (a-top left) median isotope ratio; (b-top right); median absolute deviation; (c-bottom left) quality/aggregation level; (d-bottom right) number of samples. 
have an average value of 0.7094 while samples taken from other sites on the same geological rock type (Formation 64) have an average value of 0.7089. I17 was taken from a beach while I 21 was taken $50 \mathrm{~m}$ from the Boyne estuary $800 \mathrm{~m}$ from the coast, though the presence of an impact this far inland is most likely due to the estuary. Two sites (I16 and I85) located close to the coast, however, have values distinct from 0.7092 . The first site (I16) is located on a beach and the average value is 0.7103 . This value likely represents a mixture between the marine influence, and that of the nearby Mourne Mountains, whose plant samples yield values near 0.7150 . The second (I85) is located at the Giant's Causeway in Northern Ireland and has a value of 0.7079 . While the samples from I17 and I21 were taken directly on the beach, the samples from 185 were taken from higher above (ca. $20 \mathrm{~m}$ ). The results show that in this region, the seaspray effect is limited to the immediate vicinity of the coast $(<50 \mathrm{~m})$ but that it can impact further inland under certain circumstances, such as in the case of estuaries.

Root depth and microhabitat can also affect the strontium isotope composition of plants, with a difference between grasses, shrubs and trees being as high as 0.0052 at some sites. This variability is much higher in clastic sedimentary formations (e.g. sandstones), compared to chemical sedimentary formations (e.g. limestones). This should be considered, not only when creating a map of the biologically available strontium (Fig. 5), but also when interpreting the variability in strontium isotope ratios within studied human or animal populations that may have used resources growing on such outcrops. This variability further warrants the need for multiple plant samples per location. Interestingly, out of the eleven samples categorised as outliers, seven were grasses. This could be due to the fact that they obtain their strontium from a very localised area that may not represent the location as a whole or that they could have been contaminated (e.g. fertilisers, atmospheric deposition). Furthermore, nine came from the igneous rocks groups: four from Group 2 (Felsic and intermediate igneous rocks) and four from Group 6 (Mafic igneous rocks). Though it is unclear why this is the case, particular attention should be given to samples from igneous formations in the future. In short, sampling is a crucial part of assessing the variability in the isotope ratios of the biologically available strontium of a site or region.

The isoscape presented here represents a substantial step towards a comprehensive isoscape of isotope ratio variations in the biologically available strontium of the Irish landscape. As more plant samples are measured these may be incorporated into this dataset. We also recommend that for each study, plants growing near sites of interest need to be sampled and measured to properly characterise the biologically available strontium at the site with a particular focus on plants consumed by animals and humans. This was highlighted by Madgwick et al. (2019) who measured plant samples around Navan Fort, Co. Armagh, to provide a local baseline for their Iron Age faunal data. They noted that their results $(0.7084-0.7096 ; n=7)$ fell below the range of 0.7099 to 0.7137 previously proposed for the geological formation on which Navan is located (Snoeck et al., 2016). This isoscape was based on 88 modern plants from 40 distinct locations in Northern Ireland. However, the new data presented here, based on 228 measurements from 140 locations, results in a revised characterisation of 0.7089 \pm 0.0006 , consistent with the data from Madgwick et al. (2019). While the strontium isotope ratios of animals and humans could even out the local variability seen in plants, it is important to characterise this variability to evaluate the variation that can be expected for a particular "local" animal or human population (see Snoeck et al., 2016; Fernández-Crespo et al., 2020).

This isoscape can be used as a tool to interpret the results obtained on Irish plant, animal and human samples and highlight potential regions in Ireland from which humans and animals may have sourced their food. Furthermore, based on the close proximity of the UK to Ireland, and the sharing of many geological formations it would be useful in the future to explore similarities and differences between the Irish and British maps (Evans et al., 2010). The Irish map presented here can also be useful in forensic studies to identify the possible origins of unidentified victims of crimes and natural disasters, and in food security to assess the "true" provenance of food and drink.

\section{Conclusion \& future work}

This work represents a first attempt to characterise the isotopic variation in the biologically available strontium of Ireland based on modern plants. The results clearly show variation in strontium isotope ratios highlighting the potential for mobility studies in this region. Combined with the British map (Evans et al., 2010), it is now possible to better contextualise the strontium isotope ratios measured on humans and animals from Britain and Ireland for archaeological, ecological and forensic studies. When using this map, care should be taken to consider both the variation in the values of the isotope ratios for each of the outcrops/formations (i.e. inferences should be based on both the central tendency and the variation in values, e.g. median $\pm 3 \mathrm{MAD}$, c.f. Lightfoot and O'Connell, 2016) and the range over which foods will have contributed to the diet of the humans or animals in question (i.e. inferences should be based on the values for the entire range rather than the value of a single point, e.g. BASr catchments, c.f. Snoeck et al., 2016, 2018).

Further plant measurements will facilitate a continually, more complete and comprehensive isoscape for Ireland. Therefore, at present, our recommendation is to measure plant samples, wherever possible, at each investigated site to fully characterise the "local" signal and, more importantly, its variability. The BASr baseline can be updated to include new samples by re-running the method detailed in the companion paper (Pouncett et al., n.d.). The methodology presented here for Ireland can, of course, be extended to other regions across the world. Furthermore, the differences observed between different types of plants warrant further investigation and highlight the need to rely on more than one plant sample per location for the creation of BASr baselines.

\section{Declaration of competing interest}

The authors declare that they have no known competing financial interests or personal relationships that could have appeared to influence the work reported in this paper.

\section{Acknowledgements}

We would like to thank the Philippe Wiener - Maurice Anspach Foundation (fwa.ulb.ac.be) for CS PhD fellowship and the Fonds Wetenschappelijk Onderzoek - Vlaanderen (FWO) for CS's postdoctoral fellowship. The Quaternary Research Association and the British Academy (SG130690) are acknowledged for their financial support towards the strontium isotope analyses. We are grateful to Wendy Debouge and Jeroen de Jong (G-TIME, ULB) for their help with the strontium isotope analyses. We thank Quentin Crowley (TCD) for his advice and input. We would also like to thank the editors and three anonymous reviewers for their useful comments.

\section{Appendix A. Supplementary data}

Supplementary data to this article can be found online at https://doi. org/10.1016/j.scitotenv.2019.136248.

\section{References}

Barberena, R., Tessone, A., Cagnoni, M., Gasco, A., Durán, V., Winocur, D., Benítez, A., Lucero, G., Trillas, D., Zonana, I., Novellino, P., Fernández, M., Bavio, M.A., Zubillaga, W., Gautier, E.A., 2019. Bioavailable strontium in the Southern Andes (Argentina and Chile): a tool for tracking human and animal movement. Environ. Archaeol., 1-13 https://doi.org/10.1080/14614103.2019.1689894.

Bataille, C.P., Bowen, G.J., 2012. Mapping ${ }^{87} \mathrm{Sr} /{ }^{86} \mathrm{Sr}$ variations in bedrock and water for large scale provenance studies. Chem. Geol. 304-305, 39-52. 
Bataille, C.P., Laffoon, J.E., Bowen, G.J., 2012. Mapping multiple source effects on the strontium isotopic signatures of ecosystems from the Circum-Caribbean region. Ecosphere 3 (12), 1-24.

Bataille, C.P., von Holstein, I.C.C., Laffoon, J.E., Willmes, M., Liu, X.M., Davies, G.R., 2018. A bioavailable strontium isoscape for Western Europe: a machine learning approach. PLoS One 13 (5), e0197386.

Beaumont, J., Geber, J., Powers, N., Wilson, A., Lee-Thorp, J.A., Montgomery, J., 2013. Victims and survivors: stable isotopes used to identify migrants from the Great Irish Famine to 19th century London. Am. J. Phys. Anthropol. 150, 87-98.

Bentley, R.A., 2006. Kinship and mobility during the prehistoric spread of farming: isotope evidence from the skeletons. Gen. Anthropol. 13 (1), 1 \& 7-10.

Bentley, R.A., Price, T.D., Stephan, E., 2004. Determining the "local" ${ }^{87} \mathrm{Sr} /{ }^{86} \mathrm{Sr}$ range for archaeological skeletons: a case study from Neolithic Europe. J. Archaeol. Sci. 31, 365-375.

Bowen, G.J., Wilkinson, B., 2002. Spatial distribution of $\delta^{18} \mathrm{O}$ in meteoric precipitation. Geology 30 (4), 315-318.

Cahill Wilson, J., 2012. Lost in transcription: rethinking our approach to the archaeology of the later Iron Age in Ireland. In: Corlett, C., Potterton, M. (Eds.), Life and Death in the Iron Age in Ireland. Wordwell, Bray, pp. 15-33.

Cahill Wilson, J., Standish, C.D., 2016. Mobility and migration in late Iron Age and early Medieval Ireland. J. Archaeol. Sci. Rep. 6, 230-241.

Clark, P.U., Shakun, J.D., Baker, P.A., Bartlein, P.J., Brewer, S., Brook, E., Carlson, A.E. Williams, J.W., 2012. Global climate evolution during the last deglaciation. Proc. Natl. Acad. Sci. 109 (19), E1134-E1142.

Connolly, J., Holden, N.M., Ward, S.M., 2007. Mapping peatlands in Ireland using a rulebased methodology and digital data. Soil Sci. Soc. Am. J. 71 (2), 492-499.

Copeland, S.R., Sponheimer, M., Lee-Thorp, J.A., de Ruiter, D.J., leRoux, P.J., Grimes, V., Codron, D., Berger, L.R., Richards, M.P., 2010. Using strontium isotopes to study site accumulation processes. Journal of taphonomy 8 (2), 115-127.

Copeland, S.R., Sponheimer, M., de Ruiter, D.J., Lee-Thorp, J.A., Codron, D., le Roux, P.J., Grimes, V., Richards, M.P., 2011. Strontium isotope evidence for landscape use by early hominins. Nature 474 (7349), 76-78.

Deegan, E., 2012. Sr Isotopes in the Northern Irish Biosphere. MSc.Thesis. Trinity College Dublin. School of Natural Sciences. Trinity Centre for the Environment.

Ehleringer, J.R., Bowen, G.J., Chesson, L.A., West, A.G., Podlesak, D.W., Cerling, T.E., 2008. Hydrogen and oxygen isotope ratios in human hair are related to geography. Proc. Natl. Acad. Sci. U. S. A. 105 (8), 2788-2793.

Evans, J.A., Montgomery, J., Wildman, G., 2009. Isotopes domain mapping of ${ }^{87} \mathrm{Sr} /{ }^{86} \mathrm{Sr}$ biosphere variation on the Isle of Skye, Scotland. J. Geol. Soc. Lond. 166, 617-631.

Evans, J.A., Montgomery, J., Wildman, G., Boulton, N., 2010. Spatial variations in biosphere ${ }^{87} \mathrm{Sr} /{ }^{86} \mathrm{Sr}$ in Britain. J. Geol. Soc. Lond. 167, 1-4.

Evans, J.A., Mee, K., Chenery, C., Lee, K.A., Marchant, A.P., 2018. User Guide for the Biosphere Isotope Domains GB (Version 1) Dataset and Web Portal. OR/18/005. British Geological Survey Open Report. British Geological Survey, Keyworth.

Faure, G., Powell, T., 1972. Strontium Isotope Geology. Springer, New York.

Fernández-Crespo, T., Snoeck, C., Ordoño, J., de Winter, N.J., Czermak, A., Lee-Thorp, J.A., Schulting, R.J., 2020. Multi-isotope evidence for the emergence of cultural alterity in Late Neolithic Europe. Sci. Adv.

Fick, S.E., Hijmans, R.J., 2017. Worldclim 2: new 1-km spatial resolution climate surfaces for global land areas. Int. J. Climatol. 37 (12), 4302-4315.

GSI - Geological Survey of Ireland, d. . accessed 08.09.2014. http://www.gsi.ie/.

GSNI - Geological Survey of Northern Ireland, d. . accessed 08.09.2014. http://www.bgs. ac.uk/gsni/.

Hammond, R.F., 1981. The Peatlands of Ireland. An Foras Tuńtais.

Hartman, G., Richards, M., 2014. Mapping and defining sources of variability in bioavailable strontium isotope ratios in the Eastern Mediterranean. Geochim. Cosmochim. Acta 126, 250-264.

Hess, J., Bender, M.L., Schillin, J.-G., 1986. Evolution of the ratio of strontium-87 to strontium-86 in seawater from cretaceous to present. Science 231, 979-984.

Holland, C.H., Sanders, I., 2009. The Geology of Ireland. Dunedin Academic.

Kador, T., Fibiger, L., Cooney, G.B., Fullagard, P., 2014. Movement and diet in early Irish prehistory: first evidence from multi-isotope analysis. J. Ir. Archaeol. 23, 83-96.

Kador, T., Cassidy, L.M., Geber, J., Hensey, R., Meehan, P., Moore, S., 2018. Rites of passage: mortuary practice, population dynamics, and chronology at the carrowkeel passage tomb complex, Co. Sligo, Ireland. Proceedings of the Prehistoric Society 84, 225-255.

Knudson, K.J., O’Donnabhain, B., Carver, C., Cleland, R., Price, T.D., 2012. Migration and Viking Dublin: paleomobility and paleodiet through isotopic analyses. J. Archaeol. Sci. 39 (2), 308-320.

Kootker, L.M., van Lanen, R.J., Kars, H., Davies, G.R., 2016. Strontium isoscapes in the Netherlands. Spatial variations in ${ }^{87} \mathrm{Sr} /{ }^{86} \mathrm{Sr}$ as a proxy for palaeomobility. J. Archaeol. Sci. Rep. 6, 1-13.

Laffoon, J.E., Davies, G.R., Hoogland, M.L.P., Hofman, C.L., 2012. Spatial variation of biologically available strontium isotopes $\left({ }^{87} \mathrm{Sr} /{ }^{86} \mathrm{Sr}\right)$ in an archipelagic setting: a case study from the Caribbean. J. Archaeol. Sci. 39, 2371-2384.

Lightfoot, E., O'Connell, T.C., 2016. On the use of biomineral oxygen isotope data to identify human migrants in the archaeological record: intra-sample variation, statistical methods and geographical considerations. PLoS One 11, e0153850.
Madgwick, R., Mulville, J., Evans, J., 2012. Investigating diagenesis and the suitability of porcine enamel for strontium $\left({ }^{87} \mathrm{Sr} /{ }^{86} \mathrm{Sr}\right)$ isotope analysis. J. Anal. At. Spectrom. 27 (5), 733-742.

Madgwick, R., Grimes, V., Lamb, A.L., Nederbragt, A.J., Evans, J.A., McCormick, F., 2019. Feasting and Mobility in Iron Age Ireland: Multi-isotope analysis reveals the vast catchment of Navan Fort, Ulster. Sci. Rep. 9 (1). https://doi.org/10.1038/s41598019-55671-0.

Meighan, I.G., McCormick, A.G., Gibson, D., Gamble, J.A., Graham, I.J., 1988. Rb-Sr isotopic determinations and the timing of Tertiary central complex magmatism in NE Ireland. Geol. Soc. Lond., Spec. Publ. 39 (1), 349-360.

Montgomery, J., 2010. Passports from the past: investigating human dispersals using strontium isotope analysis of tooth enamel. Ann. Hum. Biol. 37 (3), 325-346.

Montgomery, J., Grimes, V., 2010. Appendix 21.1: report on the isotope analysis of a burial from Ratoath, Co. Meath. In: Corlett, C., Potterton, M. (Eds.), Death and Burial in Early Medieval Ireland in the Light of Recent Archaeological Excavations. Wordwell, Dublin, Ireland, pp. 309-311.

Ostapkowicz, J., Brock, F., Wiedenhoeft, A.C., Snoeck, C., Pouncett, J., Baksh-Comeau, Y., Schulting, R.J., Claeys, P., Mattielli, N., Richards, M., Boomert, A., 2017. Black pitch, carved histories: radiocarbon dating, wood species identification and strontium isotope analysis of prehistoric wood carvings from Trinidad's Pitch Lake. J. Archaeol. Sci. Rep. 16, 341-358.

Poszwa, A., Dambrine, E., Ferry, B., Pollier, B., Loubet, M., 2002. Do deep tree roots provide nutrients to the tropical rainforest? Biogeochemistry 60, 97-118.

Pouncett J., Snoeck C., Ryan S. \& Schulting R. In Prep. Multi-level spatial aggregation of proxy data for isoscape mapping. Methods X.

Reynolds, A.C., Quade, J., Betancourt, J.L., 2012. Strontium isotopes and nutrient sourcing in a semi-arid woodland. Geoderma 189-190, 574-584.

Ryan, S., 2017. An Integrated Multi-Isotope and Element Distribution Study of the Irish Biosphere. Ph.D. Thesis. Trinity College Dublin. School of Natural Sciences. Geology.

Ryan, S.E., Reynard, L.M., Crowley, C.G., Snoeck, C., Tuross, N., 2018a. Early medieval reliance on the land and the local: an integrated multi-isotope study $\left({ }^{87} \mathrm{Sr} /{ }^{86} \mathrm{Sr}, \delta^{18} \mathrm{O}\right.$ $\left.\delta^{13} \mathrm{C}, \delta^{15} \mathrm{~N}\right)$ of diet and migration in Co. Meath, Ireland. J. Archaeol. Sci. 98, 59-71.

Ryan, S.E., Snoeck, C., Crowley, Q.G., Babechuk, M.G., 2018b. ${ }^{87} \mathrm{Sr} /{ }^{86} \mathrm{Sr}$ and trace element mapping of geosphere-hydrosphere-biosphere interactions: a case study in Ireland. Appl. Geochem. 92, 209-224.

Schulting, R.J., Richards, M., Pouncett, J., Naqqi Manco, B., Freid, E., Ostapkowicz, J., 2018. Absence of Saharan dust influence on the strontium isotope values on modern plants from the Bahamas and Turks and Caicos Islands. Quat. Res. 89 (2), 394-412.

Sheridan, J.A., Jay, M., Montgomery, J., Pellegrini, M., Cahill Wilson, J., 2013. "Tara boy": local hero or international man of mystery? In: Sullivan, M.O., Doyle, M., Scarre, C. (Eds.), Tara-From the Past to the Future. Wordwell, Dublin, pp. 207-232

Sillen, A., Hall, G., Richardson, S., Armstrong, R., $1998 .{ }^{87} \mathrm{Sr} /{ }^{86} \mathrm{Sr}$ ratios in modern and fossi food-webs of the Sterkfontein Valley: implications for early hominid habitat preferences. Geochim. Cosmochim. Acta 62, 2463-2473.

Snoeck, C., 2014. Impact of strontium sea spray effect on the isotopic ratio $\left({ }^{87} \mathrm{Sr} /{ }^{86} \mathrm{Sr}\right)$ of plants in coastal Ireland. Quaternary Newsletter 134, 37-39.

Snoeck, C., Lee-Thorp, J.A., Schulting, R.J., de Jong, J., Debouge, W., Mattielli, N., 2015. Calcined bone provides a reliable substrate for strontium isotope ratios as shown by an enrichment experiment. Rapid Communication in Mass Spectrometry 29, 107-114.

Snoeck, C., Pouncett, J., Ramsey, G., Meighan, I., Mattielli, N., Goderis, S., Lee-Thorp, J.A., Schulting, R.J., 2016. Mobility during the Neolithic and Bronze Age in Northern Ireland explored using strontium isotope analysis of cremated human bone. Am. J. Phys. Anthropol. 160 (3), 397-413.

Snoeck, C., Pouncett, J., Claeys, P.H., Goderis, S., Mattielli, N., Parker Pearson, M., Willis, C., Zazzo, A., LeeThorp, J.A., Schulting, R.J., 2018. Strontium isotope analysis on cremated human remains from Stonehenge support links with west Wales. Sci. Rep. 8, 10790

Thomsen, E., Andreasen, R., 2019. Agricultural lime disturbs natural strontium isotope variations: implications for provenance and migration studies. Sci. Adv. 5 (3), eaav8083.

Veizer, J., Ala, D., Azmy, K., Bruckschen, P., Buhl, D., Bruhn, F., Cardena, G.A.F., Diener, A., Ebneth, S., Godderisb, Y., Jasper, T., Korte, C., Pawellek, F., Podlaha, O.G., Strauss, H. 1999. ${ }^{87} \mathrm{Sr} /{ }^{86} \mathrm{Sr}, \delta^{13} \mathrm{C}$ and $\delta^{18} \mathrm{O}$ evolution of Phanerozoic seawater. Chem. Geol. 161 (1-3), 59-88.

Wallace, A., Montgomery, J. Grimes, V., 2010. Excavation of an early medieval cemetery at Ratoath, Co. Meath. In: Corlett, C., Potterton, M. (Eds.), Death and Burial in Early Medieval Ireland in the Light of Recent Archaeological Excavations. Wordwell, Bray pp. 335-359.

Weis, D., Kieffer, B., Maerschalk, C., Barling, J., de Jong, J., Williams, G.A., Hanano, D., Pretorius, W., Mattielli, N., Scoates, J.S., Goolaerts, G., Friedman, R.M., Mahoney, J.B., 2006. High-precision isotopic characterization of USGS reference materials by TIMS and MC-ICP-MS. Geochem. Geophys. Geosyst. 7 (8).

Whipkey, C.E., Capo, R.C., Chadwick, O.A., Stewart, B.W., 2000. The importance of sea spray to the cation budget of a coastal Hawaiian soil: a strontium isotope approach. Chem. Geol. 168 (1), 37-48. 